\title{
A HILBERT-TYPE FRACTIONAL INTEGRAL INEQUALITY WITH THE KERNEL OF MITTAG-LEFFLER FUNCTION AND ITS APPLICATIONS
}

\author{
QIONG LIU
}

\begin{abstract}
By using the theory of the local fractional calculus and the methods of weight function, a Hilbert-type fractional integral inequality with the kernel of Mittag-Leffler function and its equivalent form are given. Their constant factors are proved being the best possible, and its applications are discussed briefly.
\end{abstract}

Mathematics subject classification (2010): 26D15, 26D10.

Keywords and phrases: Fractal space, Hilbert-type fractional integral inequality, weight function.

\section{REFERENCES}

[1] G. H. Hardy, J. E. Littlewood, G. Pòlya, Inequalities, Cambridge University Press, Cambridge, 1934.

[2] D. S. Mitrinović, J. E. Pecarić, And A. M. Fink, Inequalities involving functions and their integrals and derivatives, Kluwer Academic, Boston, 1991.

[3] G. H. HARDY, Note on a theorem of Hilbert concernint series of positive terms, London Math. Soc. 23 (1925), Records of Proc., 45-46.

[4] B. C. YANG, On Hilbert's integral inequality, J. Math. Anal. Apple 220 (1998), 778-785.

[5] M. KRniĆ, J. PeČArIĆ, General Hilbert's and Hardy's inequalities, Mathematical inequalities and applications 8, 1 (2005), 29-51.

[6] I. BRnetic, J. PeČARIĆ, Generalization of Hilbert's integral inequality, Mathematical inequalities and applications 7, 2 (2004), 199-205.

[7] M. KRnić, M. GaO, J. PeČArić, AND X. GaO, On the besr constant in Hilbert's inequality, Mathematical inequalities and applications 8, 2 (2005), 317-329.

[8] B. C. YANG, The norm of operator and Hilbert-type inequalities, Science press, 2009.

[9] Q. LIU, D. Z CHEN, A Hilbert-type integral inequality with a hybrid kernel and its applications, Colloquium mathematicum 143, 2 (2016), 193-207.

[10] M. T. RASSIAS, B. C. YANG, A Hilbert-type integral inequality in the whole plane related to the hypergeometric function and the beta function, Journal of mathematical analysis and applications $\mathbf{4 2 8}$ (2015), 1286-1308.

[11] B. C. YANG, Hilbert-type integral inequality with non-homgeneous kernel, Journal of Shanghai University: Natural Science 17, 5 (2011), 603-605.

[12] H. Mo, X. SUI, D. YU, Generalized convex functions on fractal sets and two related inequalities, Abstract and Applied Analysis, Article ID636751 (2014).

[13] E. S Amet, Z. S. Menmet, Generalized pompeiu-type inequalities for local fractional integrals and its applications, Applied Mathematics and Computation 274 (2016), 282-291.

[14] W. B. SUN, Q. LIU, New inequalities of Hermite-Hadamard type for generlized convex function on fractal sets and its applications, Journal of Zhejiang University: Science Edition 44, 1 (2017), 47-52.

[15] X. J. YANG, Advanced local fractional calculus and its applications, New York: World Science Publisher, 2012.

[16] X. J. YANG, Local fractional functional analysis and its applications, Progress in Nonlinear Science 4 (2011), 1-225.

[17] J. GuY, Laplace's transform of fractional order via the Mittag-Leffler function and modified RiemannLiouville derivative, Applied Mathematics Letters 22 (2009), 1659-1664. 
[18] G. S. CHEN, Generalizations of Hoölder's and some related integral inequalities on fractal space, Math. GM 26 (2011), arXiv: 1109.5567v1.

[19] G. S. Chen, H. M. SRIVASTAVA, P. WANG, Some further generalizations of Hölder's inequality and related results on fractal space, Abstract and Applied Analysis, Article ID 832802 (2014).

[20] J. C. KuANG, Applied inequalities (3rd ed.), Shandong Science and Technology Press, Jinan, 2004. 